\title{
Deforestation and Carbon Stocks in the Surroundings of Lobéké National Park (Cameroon) in the Congo Basin
}

\author{
Zapfack L. ${ }^{1,5}$, Noiha Noumi V. ${ }^{2,5}$, Dziedjou Kwouossu P. J. ${ }^{3}$, Zemagho L. ${ }^{1} \&$ Fomete Nembot T. ${ }^{4}$ \\ ${ }^{1}$ Department of Plant Biology, Faculty of Science, University of Yaoundé I, Cameroon \\ ${ }^{2}$ Department of Biological Sciences, Faculty of Science, University of Ngaoundéré, Cameroon \\ ${ }^{3}$ Faculty of Agronomy and Agricultural Sciences, University of Dschang, Cameroon \\ ${ }^{4}$ Faculty of Science, University of Dschang, Cameroon \\ ${ }^{5}$ Research Unit on Climate Change, Cameroon \\ Correspondence: Noiha Noumi V., Department of Biological Sciences, Faculty of Science, University of \\ Ngaoundéré, Cameroon. Tel: 237-7083-5813. E-mail: noiha64@yahoo.fr
}

Received: September 6, 2012 Accepted: February 25, 2013 Online Published: March 8, 2013

doi:10.5539/enrr.v3n2p78 URL: http://dx.doi.org/10.5539/enrr.v3n2p78

\begin{abstract}
The study was carried out in the Lobéké national park located in Congo Basin with disturbed ecosystems. Five types of land uses were identified using transects; plantations, fallows, secondary forest, primary forest and wetland, covering respectively 9.84 ha, $26.66 \mathrm{ha}, 2.07 \mathrm{ha}, 25.17$ ha and $1.32 \mathrm{ha}$. We use allometric equation of Brown to calculate carbon stocks. The most significant aboveground biomass was in primary forest (172.60 $\mathrm{t} \mathrm{C/ha)}$ This value became $94.10 \mathrm{t} \mathrm{C/ha}$ when converting primary forest into plantations; for a loss of nearly $78.5 \mathrm{t} \mathrm{C/ha}$ representing more than $50 \%$ of the initial stocks. In secondary forest we had $169.26 \mathrm{t} \mathrm{C/ha;} 84.74 \mathrm{t} / \mathrm{ha}$ in young fallows and $140.86 \mathrm{t} / \mathrm{ha}$ in old fallows. So, deforestation and degradation are harmful to the environment; the conversion of a forest into a plantation can causes a loss of considerable stock of carbon per hectare of land converted. Even though agro forestry systems can lead to stock carbon, the best way of preserving our environment remain the preservation of the natural ecosystems.
\end{abstract}

Keywords: carbon lost, carbon stocks, carbon wells, Lobéké National Park

\section{Introduction}

Mature forests and growing forests stock annually a quarter of anthropogenic emissions of $\mathrm{CO}_{2}$ in their wood and soils (Bellassen, 2009). Billions of tons of carbon are sequestered in tropical forests (Nadine et al., 2007). To encourage developing countries to combat deforestation and forests degradation, Partnership Fund for the Carbon Forest (FPCF) and Fund for Forests in the Congo Basin (FFBC) were created respectively by the World Bank and the African Bank of development (ADB) (COMICAC, 2006). Today, stocks of carbon in the atmosphere increase abnormally in the order of 3 billion tons per year (Bergonzini \& Lanly, 2009). This increase is largely the result of human interventions, consequence of the use of fossil fuels and changes in the environment through deforestation and degradation of rainforests. Each year about 13 million hectares of forest are converted into other Types of Land Use (Charlie et al., 2009). In 2004, this destruction was $17.4 \%$ of total emissions of the greenhouse gas (GHG); making of the change of vegetations the second cause of global warming after the use of fossil fuels (Anaïs \& Perthuis, 2009). It should be suit to stabilize the climate by 2050 , avoiding warming of $2^{\circ} \mathrm{C}$ in comparison in 1970 (Spore, 2008), to reduce by half the global GHG emissions. The Kyoto's protocol shortly addressed the issue of deforestation in the South countries because for the moment only the industrialized countries are concerned (Lal et al., 1995). Opportunities already exist in the framework of Clean Development Mechanisms (CDM) that corresponds to investments in South (energy savings) by northern countries. Alternatives exist in deforestation issuing of carbon, particularly development of agro forestry systems that includes varies trees; very interesting from many points of view (Carbon binding, economic, environmental ...). In agro-ecosystems, changes in occupation of the land or in agricultural practices can also promote a carbon sequestration in soils (Zapfack, com. pers.). The relocation of forests and grassland on cropland fall within this framework. There will be the accumulation of the increase of the biomass and soil carbon, the first course being majority in the case of the forest by a factor 10 (rate of $5 \mathrm{t} / \mathrm{ha} / \mathrm{year}$ to a maximum 
increase of $0.5 \mathrm{t}$ to the ground). The better management of pastures and land route offers potential for sequestration $(0.1-1 \mathrm{t} \mathrm{c} / \mathrm{ha})$ that is significant at the global level considering that they cover more than 2 billion hectares (Harrisson \& Agland, 1987). Some studies have been carried out upon carbon sequestration in tropical Africa (Zapfack, 2005; Kotto et al., 1997; Ibrahima et al., 2002; Makana, 2009; Mugnier et al., 2009; Ingram \& Fernandes, 2001; Dolman, 2002; Vanden Bygaart et al., 2002).

The surrounding of Lobéké national park (Figure 1) was under a series of operations which transformed the forest environment since 1968. Large areas were transformed into secondary forest and even into land cultivated by populations which were installed later. The density of the population has increased rapidly since then. The purpose of the present study was to assess carbon stocks in disturbed ecosystems in the surrounding of the Park.

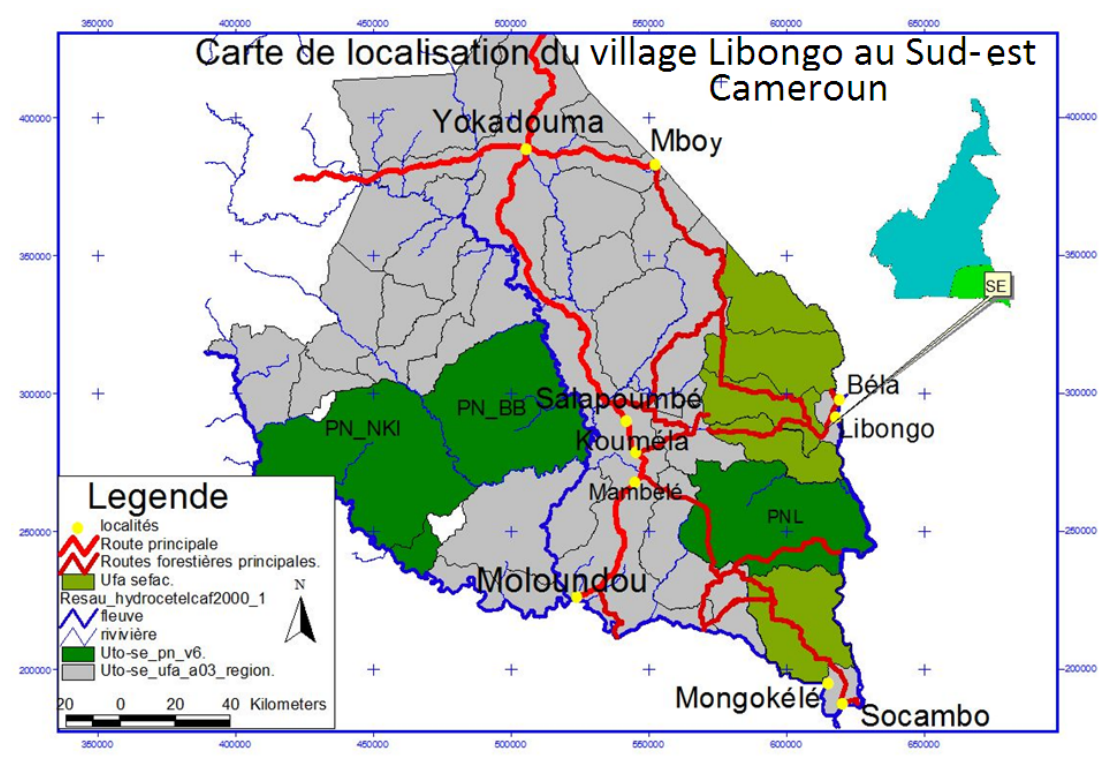

Figure 1. Localization of site (Source: SEFAC, 2010)

\section{Materials and Methods}

\subsection{Study Site}

Lobéké Park is located between latitudes $2^{\circ} 05^{\prime}$ to $2^{\circ} 30^{\prime} \mathrm{N}$ and longitudes $15^{\circ} 33^{\prime}$ to $16^{\circ} 11^{\prime} \mathrm{E}$ (Figure 1). Its area is approximately 217,854 ha. The climate is typically equatorial with four seasons. Rainfall spread throughout the year with two peaks in April and October (Ekobo, 1995). The maximum height of precipitation is approximately $1,500 \mathrm{~mm} /$ year. The Lobéké region is located in the Northwest of the Congolese basin slope, and is a part of the Congo basin with typical metamorphic formations composed essentially of quartzites, shales, limes stones and dolerites. The streams draining the area of Lobéké feed the rivers Sangha and Ngoko, two tributaries of the Congo River. On the phytogeographic plan, Lobéké region is a transitional forest between the evergreen forest of Dja and semi deciduous forest of Malvaceae and Ulmaceae (Letouzey, 1985), families according to APG II (2003).

\subsection{Sampling}

Floristic inventory was conducted by transects method (Sonké, 2004; White \& Edwards, 2000). It has advantage to cross the majority of biotopes that might exist in the ecosystem. Thus, transects of $2.5 \mathrm{~km}$ in length over $20 \mathrm{~m}$ in width were established (Figure 2) using compass. Each transect was subdivided along of $50 \mathrm{~m}$ were established by picketing. At the origin of the transect and at every $500 \mathrm{~m}$ along the transect, herbs and individuals with less than $5 \mathrm{~cm}$ DBH were inventoried in a distance of $10 \mathrm{~m}$ to assess biodiversity. Along each transect, all individuals of at least $5 \mathrm{~cm}$ of DBH were harvested. Similarly, at the origin and at every $500 \mathrm{~m}$ along each transect, samples of herbs, litter and underground root were collected. Sampling of weeds, litter and roots were collected along the transect using boards of sizes $1 \times 1 \mathrm{~m}^{2} ; 0.5 \times 0.5 \mathrm{~m}^{2}$ and $0.2 \times 0.2 \mathrm{~m}^{2}$ respectively. These samples were dried using oven in lab in order to have a constant weight. 


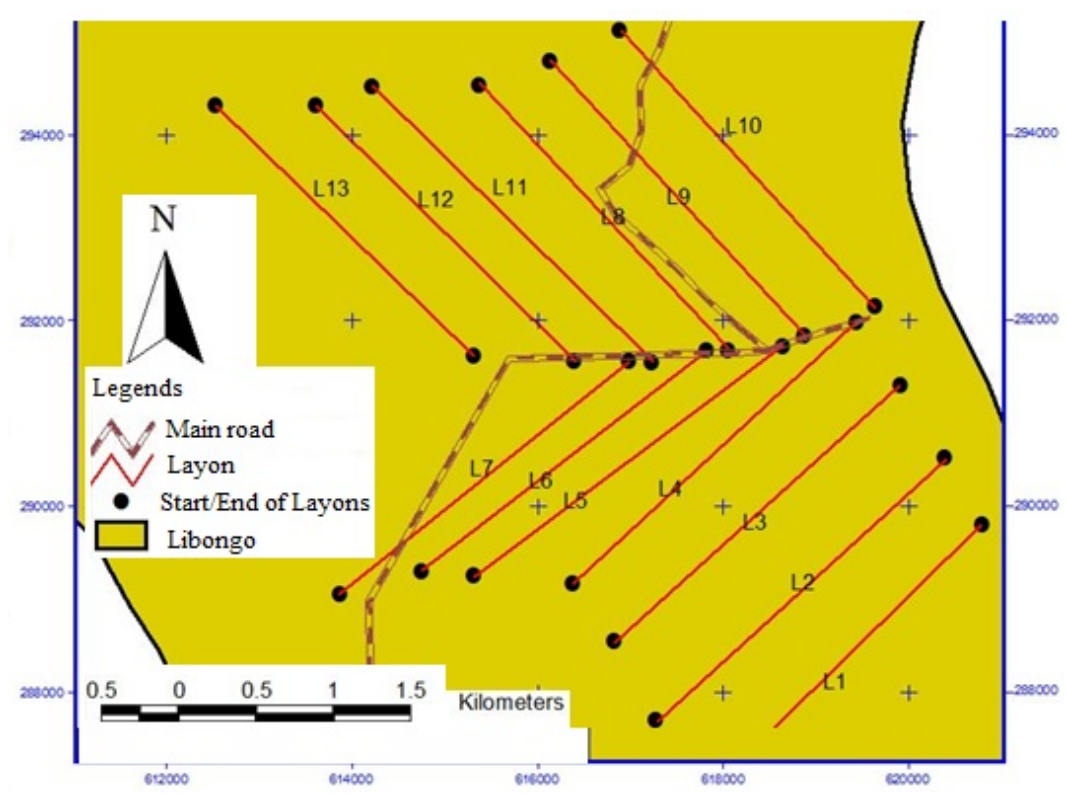

Figure 2. Localisation of transects

\subsection{Aboveground Biomass}

The DBH obtained in inventories have been used for the assessment of the mass of the carbon sequestered by the different identified individuals. The most used allometric equation in tropical forest (Brown et al., 1989) was used to calculate the carbon sequestered by each individual and infer the carbon of all woody identified:

$$
\mathrm{Y}=38.4908-11.7883 * \mathrm{D}+1.1926 * \mathrm{D}^{2}
$$

Where $\mathrm{D}$ is $\mathrm{DBH}$ in $\mathrm{cm}, \mathrm{Y}$ is biomass in tons of $\mathrm{c} / \mathrm{ha}$ and $\mathrm{R}^{2}=0.78$. From this biomass, the amount of carbon was obtained by multiplying this biomass by 0.47 .

\subsection{Belowground Biomass}

Samples of litter, small roots and herbaceous were dried in an oven until constant weight. When weight became constant after days of drying, it was concluded that all the water contained in the material is completely evaporated. Herbs, litter and underground roots' biomass were obtained by direct destruction. The roots were extracted from soil by washing the soil dug to a depth of $50 \mathrm{~cm}$. In total, 78 soil samples (i.e. $1.56 \mathrm{~m}^{3}$ of soil) were washed in the nearest stream of transect. Small-mesh sieve allowed obtaining roots from soils. Grass, litter and root samples collected in field were dried to constant weight in the laboratory for three days.

The weight of the big roots was estimated using the following formula $\mathrm{Wr}=0.0264\left(\mathrm{D}^{2} \mathrm{~L}\right)^{0.775}$ where $\mathrm{Wr}$ is the weight in $\mathrm{Kg}$, D the diameter in centimetre and $\mathrm{L}$ the length in meter. Total carbon is obtained by the sum of carbon in herbs, wood, litter and roots.

\subsection{Statistical Analyses}

We used STATISTICA 9.9 software, test ANOVA and test t STUDENT to compare data. We also used Arcview 3.3 software to draw maps.

\section{Results and Discussion}

\subsection{Diversity of Types of Land Used Identified (Figure 3)}

\subsubsection{Plantations}

In these formations we found mainly food crops and very little of annuities and fruit crops; Musa spp. (100 individuals/ha), Musanga cecropioides (14 individuals/ha), Petersianthus macrocarpus (5 individuals/ha), Trema orientalis (5 individuals/ha), Celtis spp. (4 individuals/ha), Eribroma oblongum (4 individuals/ha), Terminalia superba (4 individuals/ha), Ricinodendron heudelotii (3 individuals/ha), Pycnanthus angolensis (2 individuals/ha) and Nesogorbordonia papaverifera ( 2 individuals/ha). Plantations covered a total area of 9.84 ha $(15.14 \%)$. 


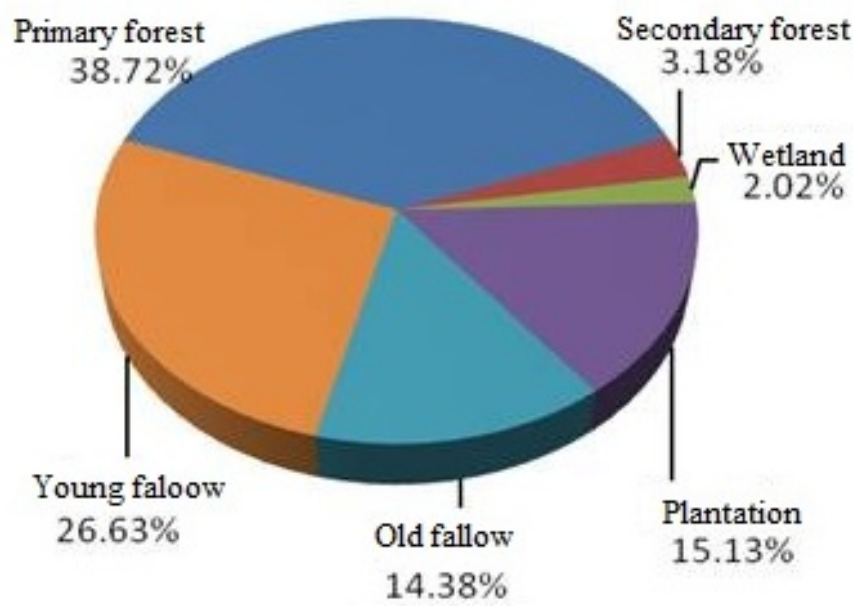

Figure 3. Proportion of the different types of land use

\subsubsection{Fallow Land (Young and Old)}

Fallows occupied 26.66 ha $(41.02 \%)$ or more than the third of the total area of the 65 ha of transects. The dominant stratum consisted primarily of Musa spp. (63 individuals/ha), of Musanga cecropioides (24 individuals/ha), of Trema orientalis ( 8 individuals/ha), of Celtis adolphi-friderici (5 individuals/ha), of Terminalia superba (5 individuals/ha), of Macaranga hurifolia (3 individuals/ha), of Eribroma oblongum (3 individuals/ha), of Mareyopsis longifolia (3 individuals/ha), of Ricinodendron heudelotii (3 individuals/ha), and Petersianthus macrocarpus (3 individuals/ha).

\subsubsection{Secondary Forests}

Secondary forest occupied 2.07 ha $(3.18 \%$ ) due to the logging which greatly facilitated the conversion of very important secondary forests in 1968. Indeed it is easier to turn a secondary forest into plantations as a primary forest because of the facilities offered by logging (opening of roads...) where the preference of the populations in these areas which have now almost disappeared. We found in this TLU a few large Musanga cecropioides (11 individuals/ha) that were gradually replaced by other species such as Gilbertiodendron dewevrei (27 individuals/ha), Mareyopsis longifolia (14 individuals/ha).

\subsubsection{Primary Forests}

Primary forests covered a substantial part of the landscape of 25.17 ha (38.72\%) after fallows. Primary forests are characterized by a mixture of evergreen and deciduous species. The most abundant species were: Mareyopsis longifolia (34 individuals/ha), Celtis adolphi-friderici (11 individuals/ha), Diospyros spp. (15 individuals/ha), Polyalthia suaveolens (8 individuals/ha), Rinoria sp. (6 individuals/ha), Petersianthus macrocarpus (6 individuals/ha). We found this vegetation away from inhabited areas generally $1.500 \mathrm{~m}$ or $2.000 \mathrm{~m}$. it represents a significant proportion, including more than $50 \%$ of the transect area. This can be explained by two main reasons. These areas were most often very remote of the main area housing and difficult to access by the people (very rugged land) or unsuitable for agriculture (swamps, flooded in offices areas).

\subsubsection{Wetlands}

With about 1.32 ha $(2.03 \%)$, these formations are all located along the rivers that feed the Sangha River. These areas are generally unsuitable for agriculture and are difficult to access. We met, especially species of the genera Mitragyna (80 individuals/ha) and Macaranga (25 individuals/ha) but also some Musanga cecropioides (8 individuals/ha) dispersed.

On the set of transects in the site, plantations and fallows were well represented. About $56.16 \%$ of inventory lands were already grown at least once. Human pressure on the forest is so mean as a whole but very emphasized around the main area settlement because these areas are a very low proportion of non-cultivated land and this most often more than $2 \mathrm{~km}$ of habitat. Non-crop swamp, primary and secondary forests represent $43.84 \%$ of landscape. In these three TLU, marks of anthropogenic activities only translate scattered across traps (subsistence hunting), so products are essentially intended for own consumption while a small portion is regularly sold in villages. 


\subsection{Carbon Stocks}

\subsubsection{Aboveground Biomass}

Carbon stocks vary significantly between the types of land used (One-way ANOVA, $F=4.568 ; p=0.0011$, Table $1)$.

Table 1. Amount of aboveground biomass in different types of land used

\begin{tabular}{ccccccc}
\hline Types of land used & Primary forest & Secondary forest & Old fallow & Wetland & Young fallow & Plantation \\
\hline Amount (t C/ha) & $123.76 \mathrm{ab}$ & $118.60 \mathrm{ab}$ & $105.70 \mathrm{abc}$ & $88.49 \mathrm{bc}$ & $65.27 \mathrm{c}$ & $60.22 \mathrm{c}$ \\
Standard deviation & \pm 34.32 & \pm 36.62 & \pm 33.81 & \pm 55.55 & \pm 15.01 & \pm 17.31 \\
\hline
\end{tabular}

Notes: Data affected with same letter explain that there is no significant difference between them.

The most important aboveground biomass is found in primary forest. This amount decreases gradually from secondary forest to plantation. Carbon in primary forest decreases from $123 \mathrm{t} \mathrm{C} / \mathrm{ha}$ to $60 \mathrm{t} \mathrm{C} / \mathrm{ha}$ when converting forest into plantation. This conversion leads to a loss of more than $50 \%$ of initial stocks that can return to the atmosphere. These carbon losses are especially due to forest exploitations and agriculture. This amount is less than $267.29 \mathrm{t} \mathrm{C} /$ ha obtained in primary forests in southern Cameroon. Zapfack (2005) estimated carbon stocks for all trees with a $\mathrm{DBH} \geq 4 \mathrm{~cm}$ justifying its higher value carbon stocks per hectare. In this study, only timbers of a $\mathrm{DBH} \geq 10 \mathrm{~cm}$ were harvested.

In secondary forest, the biomass is greater than $57.34 \mathrm{t} \mathrm{C}$ /ha found in Congo (Mosango, 1991) and less than $186.92 \mathrm{t} \mathrm{C/ha}$ found in southern Cameroon (Zapfack, 2005).

The amounts of carbon increase from young fallow to old fallow. These amounts are close to that of Zapfack (2005) and comparable to the amount of carbon obtained by Kanmegne et al. (1999) in young fallows of Alchornea in humid lands in Cameroon.

In plantations, we noted that, carbon stocks depend of the age of the plantations, the types of culture and the density of timbers left when creating farms. Ten important timbers were harvested according to the amount of carbon stock: Ceiba pentandra (0.626 t C/ha), Entandrophragma cylindricum $(0.548 \mathrm{t} \mathrm{C/ha),} \mathrm{Milicia} \mathrm{excelsa}$ $(0.453 \mathrm{t} \mathrm{C} / \mathrm{ha})$, Anonidium mannii $(0.437 \mathrm{t} \mathrm{C/ha})$, Pericopsis elata $(0.420 \mathrm{t} \mathrm{C} / \mathrm{ha})$, Gilbertiodendron dewevrei $(0.408 \mathrm{t} \mathrm{C} / \mathrm{ha})$, Erythrophloeum ivorense $(0.404 \mathrm{t} \mathrm{C} / \mathrm{ha})$, Guarea thompsonii $(0.371 \mathrm{t} \mathrm{C} / \mathrm{ha})$, Alstonia boonei $(0.341$ $\mathrm{t} \mathrm{C/ha)} \mathrm{et} \mathrm{Gambeya} \mathrm{beguei}(0.33 \mathrm{t} \mathrm{C/ha)}$.

\subsubsection{Belowground Carbon}

There is no significant difference between the types of land used at $p=0.05$ (Table 2). The amount of belowground biomass is important in primary forest. This amount decreases gradually; secondary forest, old fallow, plantations, young fallow and wetland (Table). It is noted that, the amount obtained in primary forest is in contrast with that of plantations; we note a loss of $14.22 \mathrm{t} \mathrm{C/ha}(38 \%)$ when converting primary forest into plantations.

Table 2. Amount of belowground biomass in different types of land used

\begin{tabular}{ccccccc}
\hline Types of land used & Primary forest & Secondary forest & Old fallow & Plantation & Young fallow & Wetland \\
\hline Amount ( $\mathrm{t} \mathrm{C/ha)}$ & $37.17 \mathrm{a}$ & $36.67 \mathrm{a}$ & $29.89 \mathrm{a}$ & $22.95 \mathrm{a}$ & $20.19 \mathrm{a}$ & $19.64 \mathrm{a}$ \\
Standard deviation & \pm 12.32 & \pm 21.02 & \pm 12.27 & \pm 21.04 & \pm 9.66 & \pm 21.04 \\
\hline
\end{tabular}

Notes: Data affected with same letter explain that there is no significant difference between them.

\subsubsection{Litter}

There is no significant difference between the types of land used (one-way ANOVA, $F=8.180 ; p>0.05$, Table 3 ). The amounts of carbon from plantations, old fallows and primary forest are comparable with those obtained in evergreen forest in south Cameroon (Kanmegne, 2004). In secondary forest, the amount of carbon is lower than that of Mosango (1991) in Democratic Republic of Congo. Mosango (1991) thought the amount of carbon of litter vary between $2.63 \mathrm{t} \mathrm{C} / \mathrm{ha}$ and $7.19 \mathrm{t} \mathrm{C} / \mathrm{ha}$. Our results match with the gap of the variation of carbon stocks. 
Table 3. Amount of litter biomass in different types of land used

\begin{tabular}{ccccccc}
\hline Types of land used & Old fallow & Plantation & Primary forest & Secondary forest & Young fallow & Wetland \\
\hline Amount (t C/ha) & $5.56 \mathrm{a}$ & $4.91 \mathrm{a}$ & $4.37 \mathrm{a}$ & $3.27 \mathrm{a}$ & $2.91 \mathrm{a}$ & $2.43 \mathrm{a}$ \\
Standard deviation & \pm 3.64 & \pm 2.54 & \pm 1.95 & \pm 0.49 & \pm 1.27 & \pm 1.05 \\
\hline
\end{tabular}

Notes: Data affected with same letter explain that there is no significant difference between them.

\subsubsection{Herbaceous}

There is also no significant difference between the types of land used (one-way ANOVA, $F=8.179 ; p>0.05$, Table 4). Carbon stocks vary little in herbaceous.

Table 4. Amount of herbaceous biomass in different types of land used

\begin{tabular}{ccccccc}
\hline Types of land used & Old fallow & Primary forest & Secondary forest & Young fallow & Wetland & Plantation \\
\hline Amount (t C/ha) & $1.02 \mathrm{a}$ & $0.76 \mathrm{a}$ & $0.73 \mathrm{a}$ & $0.65 \mathrm{a}$ & $0.75 \mathrm{a}$ & $0.56 \mathrm{a}$ \\
Standard deviation & \pm 0.64 & \pm 0.34 & \pm 0.32 & \pm 0.23 & \pm 0.28 & \pm 0.29 \\
\hline
\end{tabular}

Notes: Data affected with same letter explain that there is no significant difference between them。

\subsubsection{Overall Amount of Carbon}

The overall amount of carbon stock varies significantly between the types of land used (one-way ANOVA; $F=$ 3.971; $p=0.00308$; Table 5).

Table 5. Overall amount of biomass in different types of land used

\begin{tabular}{ccccccc}
\hline Types of land used & Primary forest & Secondary forest & Wetland & Old fallow & Plantation & Young fallow \\
\hline Amount (t C/ha) & 172.60 & 169.26 & 167.042 & 140.86 & 94.10 & 84.74 \\
Standard deviation & \pm 25.51 & \pm 49.51 & \pm 59.10 & \pm 25.36 & \pm 17.30 & \pm 18.95 \\
\hline
\end{tabular}

The overall amount of carbon found in primary forest is comparable with that of Kanmegne (2004) in ever green forest in south Cameroon (199 t C/ha). This amount is more than $137.70 \mathrm{t} \mathrm{C/ha}$ obtained by Nolte et al. (2001) in the same types of land used in south Cameroon; Nolte et al. did not take into account the biomass of herbaceous and roots. However, in the same forest, Ibrahima (2002) found $281.53 \mathrm{t} \mathrm{C} / \mathrm{ha}$ in primary forest and Mosango (1991) $222.78 \mathrm{t} \mathrm{C/ha}$. These authors considered timber of a DBH less than $10 \mathrm{~cm}$. Data obtained in this study are considerably higher than those from the agro systems in the center of Himalaya in India and in tropical humid dense forest in Costa Rica (Prakash \& Lodhiyal, 2009; William et al., 2011; Chavan \& Rasal, 2012).

\subsection{Economic Value}

To estimate the commercial value of the potential of woody in forests, we assumed the upgrading of all exploitable species only in logs without exception. In order to make a comparison on a realistic basis we also took into account the DMEad (Minimum Diameter of Exploitability administrative) of all exploitable species. Table 6 presents raw volumes, market volumes and economic value of marketable species identified in all types of land used. As shown in Table 6 the total marketable volume of primary forest represents itself only about $50 \%$ of the marketable potential (2183.95 $\mathrm{m}^{3}$ equivalent to $133,376,397.2$ CFA francs). The conversion of this primary forest into plantations results in a reduction of raw volume of $74 \%$ for a financial loss estimated at 2,375,225 $\mathrm{CFA} \mathrm{F/ha} \mathrm{of} \mathrm{converted} \mathrm{land.} \mathrm{At} \mathrm{the} \mathrm{same} \mathrm{time,} \mathrm{the} \mathrm{increase} \mathrm{in} \mathrm{monetary} \mathrm{value} \mathrm{per} \mathrm{unit} \mathrm{area} \mathrm{of} \mathrm{marketable} \mathrm{species}$ from plantations to forest is justified by the reconstitution of the ecosystems over time; that is to say the increase in biomass following the sequence plantation, young and old fallows, secondary forest and finally primary forest as the climax stage. 
Table 6. Dealer/Economic value of timbers

\begin{tabular}{ccccc}
\hline TLU & Raw volume $\left(\mathrm{m}^{3}\right)$ & Dealer volume $\left(\mathrm{m}^{3}\right)$ & Economic Value (F cfa) & Economic Valeur/ha \\
\hline Primary forest & 2729.94 & 2183.95 & $133,376,397.2$ & $5,299,443.627$ \\
Secondary forest & 270.48 & 216.38 & $11,650,451.51$ & $5,628,237.444$ \\
Wetland & 93.14 & 74.51 & $4,674,121.721$ & $3,546,374.599$ \\
Plantation & 712.25 & 569.80 & $28,768,469.46$ & $2,924,219.299$ \\
Young fallow & 917.03 & 733.63 & $47,943,112.91$ & $2,769,677.233$ \\
Old fallow & 840.43 & 672.34 & $38,269,025.06$ & $4,092,943.857$ \\
Total & 5563.29 & 4450.63 & $264,681,577.8$ & $/$ \\
\hline
\end{tabular}

\subsection{Ecological Value}

The stocks of $\mathrm{CO}_{2}$ decrease from primary forests to plantations (Table 7); during the conversion of a primary forest into plantations carbon stocks spend from 17, 463.01 tons to $3,394.64$ tons and more than $50 \%$ tons of $\mathrm{CO}_{2}$ per hectare return to the atmosphere. For the ecological value point of view, there is a clear will to urge the world community to limit the maximum degradation and deforestation. Indeed the total ecological value per unit area of the carbon dioxide in the case of the study site was 1,718,547.241 CFA francs in primary forests and 694,388.183 CFA francs in plantations; for a difference of more than 1,000,000 CFA F.

Table 7. Ecological value of the harvested timbers

\begin{tabular}{cccc}
\hline TUT & ${\text { Total } \mathrm{CO}_{2}(\mathrm{t})}$ & Ecological value (F cfa) & Ecological value/ha \\
\hline Primary forest & $17,463.01$ & $43,252,396.95$ & $1,718,547.24$ \\
Secondary forest & $1,182.829$ & $3,784,100.83$ & $1,828,068.03$ \\
Wetland & 540.84 & $1,339,564.45$ & $1,016,361.49$ \\
Plantation & $3,394.64$ & $6,831,390.94$ & $694,388.18$ \\
Young fallow & $5,084.62$ & $10,232,299.2$ & $591,120.69$ \\
Old fallow & $4,244.67$ & $8,541,977.49$ & $913,580.52$ \\
Total & $31,910.63$ & $73,981,729.89$ & $/$ \\
\hline
\end{tabular}

\subsection{Comparison between Ecological and Commercial Values}

Comparison of economic and ecological values in the different types of land used is summarized in Table 8 . The commercial value of different types of land used is greater than the ecological value. In the case of our sample unit this difference was 190,699,847.9 CFA F. In fact, considering the rotation period (space of time between two successive passage of the operation at the same location) which is 30 years in Cameroon (order 0222/A/MINEF of 25 May 2001), laying down the procedures for the preparation, approval, monitoring and review of the implementation of management plans for forests for the production of the permanent forest estate in article 6 , paragraph (g), it can be said that it takes 30 years to the State to obtain again the amount equivalent to the commercial value of such logs per unit area; for an amount of 5,299,443.627 F.cfa/ha every 30 years looking for this study the case of primary forests (Table 8).

Ecological value is paid in 3 years interval. Considering the case of primary forests, this would require that every three years the State should cash a sum equivalent to 1,718, 547.241 CFA F/ha; for 6,874,188.964 CFA F/ha of primary forest after 12 years. This means that after 4 payments on the 10 normally expected to reach the 30 years, the ecological value per unit area in the case of primary forests will be already superior to its commercial value for a total difference of $11,886,028.78 \mathrm{~F} \mathrm{cfa} / \mathrm{ha}$ after the 30 years. In conclusion the carbon market is much more cost effective than the wood market considering as reference for the duration of rotation. 
Table 8. Comparison between Dealer/Economic values of timbers

\begin{tabular}{ccc}
\hline TLU & $\begin{array}{c}\text { Difference between Dealer/Economic value } \\
\text { of timbers (F cfa) }\end{array}$ & $\begin{array}{c}\text { Difference between Dealer/Economic value } \\
\text { of timbers (F cfa/ha) }\end{array}$ \\
\hline Primary forest & $901,124,000.25$ & $5,628,237.44$ \\
Secondary forest & $7,866,350.67$ & $3,800,169.40$ \\
Wetland & $3,334,557.27$ & $2,530,013.10$ \\
Plantation & $21,937,078.51$ & $2,229,831.16$ \\
Young fallow & $37,710,813.71$ & $2,178,556.54$ \\
Old fallow & $29,727,047.56$ & $3,179,363.33$ \\
Total & $190,699,847.9$ & $/$ \\
\hline
\end{tabular}

\section{Conclusion}

Comparative analysis of the two possibilities of valorisation of the forest vegetation shows that in the short term business value is more cost-effective than the ecological value. In fact, approximately 12 years out of the 30 references (rotation) are needed to reverse this trend. This difference led to say that ecological valorisation is more cost effective and of a major importance for the Congo Basin forests both in economic and environmental terms. It is therefore imperative for the authorities in charge of the forest to find a compromise between the two modes of recovery of woodland while searching for the balance between the development in advocates for environmental purposes and rights of uses enjoyment of communities for economic purposes. The conversion of forest into plantation leads to a loss of important quantities of $\mathrm{CO}_{2}$. This amount of dioxide carbon is harmful to the environment.

\section{Acknowledgments}

The authors are very grateful to the "Foundation de la Tri-Nationale de la Sangha (FTNS)". Authors are grateful to the Executive Director. This work was initiated and funded by the project "Biodiversity and carbon sequestration in the national park of Lobéké".

\section{References}

Anaïs, D., \& Perthuis, C. (2009). Les marchés du carbone expliqués. Bureau du pacte mondial de l'ONU, USA. p. 40.

APG II. (2003). An update of the angiosperm phylogeny group classification for the orders and families of flowering plants. Botanical Journal of the Linnean Society, 141, 399-436. http://dx.doi.org/10.1046/j.1095-8339.2003.t01-1-00158.x

Bellassen, V. (2009). Les forêts et les émissions de $\mathrm{CO}_{2}$. Le Flamboyant, 84, $72-77$.

Bergonzini, J. C., \& Lanly, J. P. (2009). La forêt et la gestion du carbone. Le Flamboyant, 84, 71.

Brown, S., Gilespie, A. J. R., \& Lugo, A. E. (1989). Biomass estimation methods for tropical forest with application to forest inventory data. For. Sci., 35, 881-902.

Charlie, P., Andrew, M., Mandar, T., \& Niki, M. (2009). Le Petit Livre Rouge du REDD ${ }^{+}$Guide de propositions gouvernementales etnongouvernementalesvisant à réduire lesémissions liées à ladéforestation et à ladégradation de la forêt. Deuxième édition, Global Canopy programme.WWW.littleREDDbook.org. p. 71.

Chavan, B. L., \& Rasal, G. B. (2012). Carbon sequestration potential of young a reticulate and Annonasquamosa from University campus of Aurangabad. International Journal of Physical and Social Sciences, 2(3), 193-198.

Commission des Forêts d'Afrique Centrale (COMICAC). (2006). Etats des forêts du Bassin du Congo. COMIFAC, Yaoundé, p. 256.

Dolman, A. J., Moors, E. J., \& Elbers, J. A. (2002). The carbon uptake of a mid latitude pine forest growing on sandy soil. Agriculture and forest Meteorology, 111, 157-170. http://dx.doi.org/10.1016/S0168-1923(02)00024-2

Ekobo, A. (1995). Conservation of the African forest elephant (Loxodonta Africana cyclotis) in Lobéké, Southeast Cameroon. Ph. D. thesis, University of Kent, p. 151. 
Harrisson, M., \& Agland, P. (1987). A draft proposal for the designation of three new national forest parks. Dja River Films, LTD.

Ibrahima, A., Schmidt, P., Ketner, P., \& Mohren, G. J. M. (2002). Phytomasse et cycle des nutriments dans la forêt tropicale dense humide du sud Cameroun. The Tropenbos-Cameroon Programme, Kribi, Cameroon. Tropenbos-Cameroon, p. 81.

Ingram, J. S. I., \& Fernandes, E. C. M. (2001). Managing carbon sequestration in soils: concepts and terminology. Agriculture. Ecosystems and Environment, 87, 111-117. http://dx.doi.org/10.1016/S0167-8809(01)00145-1

Kanmegne, J., Duguma, B., Henrot, J., \& Isirimah, D. O. (1999). Soil fertility enhancement by planted tree fallow species in humid lowland of Cameroon. Agroforestry System. http://dx.doi.org/10.1023/A:1005902823936

Kanmegne, J. (2004). Slash and burn agriculture in the humid forest zone of southern Cameroon: Soil quality dynamics, Improved fallow, Management and farmers'perception. Wageningen University.

Kotto, J., Woomer, P. L., Moukam, A., \& Zapfack, L. (1997). Carbon dynamics in slash and burn agriculture and land use alternatives in the humid forest zone of Cameroon. Agriculture, Ecosystems and environment, 65(3), 245-246. http://dx.doi.org/10.1016/S0167-8809(97)00060-1

Lal, R., Kimble, J., Levine, E., \& Stewart, B. A. (1995). Soils and Global Change. CRC/ Lewis Publishers, Boca Raton, FL.

Letouzey, R. (1985). Notice de la carte phytogéographique du Cameroun au 1:500.000. Institut de la cartographie internationale de la végétation, Toulouse, France.

Makana, J. R. (2009). Mesure des stocks de carbone aérien dans les forêts du Bassin du Congo. Wild life Conservation Society

Mosango, M. (1991). Contribution à l'étude botanique et biogéochimique de l'écosystème forêt en région tropicale (île Kongolo, Zaïre). Belgium Journal of Botany, 124(2).

Mugnier, A., Cassagne, B., Bayo, N., \& Lafon, C. (2009). Estimation des stocks de carbone des forêts du bassin du Congo pour le REDD: étude comparative conduite sur 22 types forestiers, 4 pays et un dispositif d'aménagement de 4,8 millions d'ha, p.11.

Nadine, L., Frank, M., Alessandro, B., Scott, G., Richard, H., Jared, S., \& Maria, B. (2007). Réduire les émissions de $\mathrm{CO}_{2}$ du déboisement et de la dégradation dans la République Démocratique du Congo: un premier apercu, p. 28.

Prakash, S., \& Lodhiyal, L. S. (2009). Biomass and Carbon Allocation in 8-year-old Poplar (Populusdeltoides Marsh) Plantation in Tar Agroforestry Systems of Central Himalaya, India. New York Science Journal, 2(6), 49-53.

Sonké, B. (2004). Forêts de la réserve du Dja (Cameroun). Etude floristique et structurale. Meise, Jardin Botanique National de Belgique, p. 144.

Spore. (2008). Hors-série. Changements climatiques, p. 24.

Vanden Bygaart A. J., Yang, X. M., Kay, B. D., \& Aspinall, J. D. (2002). Variability incarbon sequestration potential in no-soil landscapes of southern Ontarion. Soil \&tillageResearch, 65, 231-241. http://dx.doi.org/10.1016/S0167-1987(02)00003-X

White, L., \& Edwards, A. (2000). Conservation en forêtpluvialeafricaine. Méthodes de recherches. Wildlife Conservation Society, New York, p. 444.

William Fonseca, Federico, E., \& Jose Rey-Benayas. (2011). Carbon accumulation in aboveground and belowground biomass and soil of different age native forest plantations in the humid tropical lowlands of Costa Rica. New Forest, p. 17.

Zapfack, L. (2005). Impact de l'agriculture itinérante sur brûlis sur la biodiversité végétales et la séquestration du carbone. Thèse de doctorat d'Etat. Université de Yaoundé I, p. 194. 